\title{
Plant Responses to UV Blocking Greenhouse Covering Materials: A Review
}

\author{
Nikolaos Katsoulas ${ }^{1, *} \mathbb{C}$, Anastasia Bari ${ }^{1}$ and Chryssoula Papaioannou ${ }^{2, *}$ \\ 1 Department of Agriculture Crop Production and Rural Environment, School of Agricultural Sciences, \\ University of Thessaly, Fytokou Str, 38446 Volos, Greece; bari@uth.gr \\ 2 Department of Agrotechnology, School of Agricultural Sciences, University of Thessaly, 41500 Larisa, Greece \\ * Correspondence: nkatsoul@uth.gr (N.K.); chpapa@uth.gr (C.P.); Tel.: +30-2421093249 (N.K.); \\ $+30-2410684524$ (C.P.)
}

Received: 1 June 2020; Accepted: 12 July 2020; Published: 15 July 2020

check for updates

\begin{abstract}
Pure polyethylene (PE) is enriched with several additives to make it a smart application material in protected cultivation, as a cover material for either greenhouses or screenhouses. When this material completely or partially absorbs ultraviolet (UV) solar radiation, then it is called UV blocking material. The current work presents a review on the effects of the UV blocking covering materials on crop growth and development. Despite the passage of several years and the evolution of the design technology of plastic greenhouse covers, UV blocking materials have not ceased to be a rather interesting technique for the protection of several vegetable and ornamental species. Much of the research on UV blocking materials focuses on their indisputable effect on reducing the activity of pests and viral-related diseases, rather than on the effects on the crop physiology itself. In the present paper, representative studies dealing with the effect of the UV blocking materials on the agronomic factors of different crops are presented and discussed. The results reveal that UV blocking materials have mainly positive effects on the different plant physiological functions, such as photosynthesis and transpiration rate, and on growth characteristics, while they might have a negative effect on the production and content of secondary compounds, as anthocyanins and total phenolics.
\end{abstract}

Keywords: polyethylene; ultraviolet radiation; crop response; fruit color pigmentation; vegetative growth

\section{Introduction}

The concern for safer food and environmental protection is increasing among consumers. Regulations on maximum residue limits in crop products are becoming stricter. Growers'/retailers' commercial contracts often demand minor pesticide use within cultivation procedure. In addition, the production cost of vegetables could be reduced by adopting techniques with limited chemical use and alternative methods for sufficient pests and diseases control. In this direction, the use of UV blocking greenhouse covering materials is aligned with the creation of an unfavorable environment for greenhouse crops enemies. Many authors [1-4] pointed out that the use of UV blocking films as greenhouse cover leads to decreased insect population and fungal diseases. Thus, a significant number of greenhouse growers indeed uses such type of films. However, these materials also have several effects on crop growth and development. Plant responses to UVB can be photomorphogenetic and protective [5].

Growth and development of plants depends on the presence of photoreceptors (phototropins, cryptochrome and phytochrome). Phototropins have the ability to mediate light responses and optimize the photosynthetic yield. The UVA/blue light sensing cryptochromes and the red/far-red sensing phytochromes coordinately can control seedling establishment, entrainment of the circadian clock, and the transition from vegetative to reproductive growth. Moreover, phytochromes are the main photoreceptors to control seed germination and shade-avoidance responses [6]. 
Red and Far Red light is absorbed by phytochromes that are related to photo-morphogenetic reactions of the plants. However, photo-morphogenetic responses have been also reported as plant reaction to UV light region [7].

Photo-morphogenetic responses to UV radiation are mediated by the photoreceptor UV Resistance Locus8 (UVR8). Transcriptome analyses in many species have demonstrated that exposure to UVB radiation differentially regulates the expression of hundreds of genes in diverse functional categories. UV radiation can change cell membrane characteristics that may not only result in changes in membrane permeability and ionic balance, but may also be ultimately responsible for the partial inhibition of photosynthesis and respiratory changes [8]. Respiration depends primarily on photosynthesis, as the respiration process consumes the carbons that are produced from photosynthesis [9].

Regarding the greater accumulation of secondary compounds in the presence of UV radiation, it has been reported that these compounds accumulate in leaves of higher plants to screen out harmful UV radiation [10]. UV-absorbing pigments such as flavonoids protect the plant by specifically absorbing in the 280-340 $\mathrm{nm}$ wavelength region, thus decreasing UV penetration into underlying tissue [11]. UV radiation also has an indirect damaging effect on the chlorophyll a and b contents of plants [12], and thus a higher photosynthesis rate may be expected under absence of UV light. Plant secondary metabolites that are affected by UV light, are important due to their health-promoting properties. Use of UV blocking covering materials can lead to a reduction in secondary plant compounds, such as phenolics, flavonoids and carotenoids.

Stomatal behavior is also affected by UV radiation, although it is an integrated response to a large number of environmental factors including $\mathrm{CO}_{2}$, humidity, radiation, temperature and water supply. It has been found that $\mathrm{UV}$ radiation can affect stomatal behavior in a wavelength dependent manner. UVA wavelengths stimulate the opening of stomata, while UVC may induce stomatal closure [11].

When reviewing the relevant scientific findings, it was observed that most of the research work conducted usually had the study of the effects of UV blocking greenhouse covering materials on pests and diseases as a primary objective, while the effects on the greenhouse environment and on crop growth and development are usually a secondary objective.

The aim of this work is to present a review of the research carried out in relation to the effects of UV blocking greenhouse covering films on crop growth and development. The review includes some definitions for solar radiation and a presentation of the different types of greenhouse covering materials tested for their UV radiation properties around the world. It makes an assessment of the effects of the UV blocking covering materials on plant functions, as photosynthesis, respiration, transpiration, germination, seedlings and pigment synthesis. Plants growth characteristics as roots, leaves and stems growth, flowering and fruit setting, but also plant performance, yield and earliness, have been studied. Moreover, this review presents the instrumentation and the methodology needed to identify, quantify and evaluate the effects of the UV blocking covering materials on crop growth and development. Finally, a discussion on the differences observed between the different regions and crops studied is given.

The solar radiation that enters in a greenhouse is ranging mainly between $280 \mathrm{~nm}$ and $3000 \mathrm{~nm}$ [13]. Taking into account the effects of solar radiation on plant growth and development, the above range can be divided in three basic wavebands, namely: Ultraviolet radiation (UV: $280-400 \mathrm{~nm}$ that is also divided in UVB: $280-320 \mathrm{~nm}$ and UVA: $320-400 \mathrm{~nm}$ ), Photosynthetically Active Radiation (PAR: 400-700 nm), and Near Infrared Radiation (NIR: 700-1400 nm) [14].The percentage of UV, PAR and NIR parts of solar energy incident in open field during a clear day varies from $2.8 \%$ to $7 \%, 42.7 \%$ to $71 \%$, and $30 \%$ to $54 \%$, respectively [15], while the UV radiation is further divided into UVA ( $95 \%$ ) and UVB (5\%) [16].

Since the cover is exposed to different ambient conditions, it usually consists of many layers in order to improve its strength, durability, anti-dripping, etc., as well as its radiometric properties. Many types of plastic are used in protected cultivation as covering materials. The most common plastic material is polyethylene (PE), but many others such as polyvinyl chloride (PVC), ethylene vinyl acetate (EVA), polyester, etc. are also used. The right cover has to have many properties not only to address harsh 
environmental conditions but also to conserve resources (energy, water, capital, etc.). For all these reasons, different additives are included in a cover material in order to transform it to a clever 'greenhouse covering material'. These additives intend to lead mainly to optimal light transmission, provide UV stabilization (UV additives), reduce heat losses (IR additives) and reduce condensation (AF additives) and formation of droplets (AD additives). The different types of plastics used in different research studies worldwide in relation to the UV blocking effect on greenhouse covering materials include:

- PE films, tested in Finland [17], Israel [18], Spain [19-22], UK [10,23-25], Greece [26-28], Serbia [29], Germany [30], USA [31] and Australia [32];

- $\quad$ Polyester tested in USA [33], Finland [17], India [34-36], Italy [37] and China [38];

- $\quad$ PVC films tested in Japan [39];

- Plexiglas tested in Belgium [40] and Germany [41];

- Ethylene-tetrafluorethylene (ETFE) films tested in Germany [42,43];

- EVA films tested in Japan [44] and in Ethiopia [45];

- Cellulose diacetate tested in USA [33], China [38], in Japan [46], and Bangladesh [47,48];

- Teflon and polycarbonate (PC) films tested in USA [49].

The country of study, the year of the study and the UV radiation region that is blocked by the different UV blocking materials referred in the current review, are presented in Table 1.

Table 1. Country, year and UV blocking region of the materials studied in the literature that is referred in the current review.

\begin{tabular}{|c|c|c|c|}
\hline Reference & Country & Year & UV Blocking Materials Studied \\
\hline [4] & US & 2002 & 2 materials blocking radiation $<360$ and $<380 \mathrm{~nm}$ \\
\hline [10] & UK & 2008 & $\begin{array}{l}6 \text { materials blocking radiation }<280 \mathrm{~nm},<320 \mathrm{~nm},<350 \mathrm{~nm},<370 \mathrm{~nm} \text {, } \\
<380 \mathrm{~nm},<400 \mathrm{~nm}\end{array}$ \\
\hline [17] & FI & 1999 & 3 materials blocking radiation $<315 \mathrm{~nm},<360 \mathrm{~nm},<400 \mathrm{~nm}$ \\
\hline [18] & IL & 2003 & 1 material blocking radiation $<300 \mathrm{~nm}$ \\
\hline [19] & ES & 2009 & 3 materials blocking radiation $<300 \mathrm{~nm},<315 \mathrm{~nm},<380 \mathrm{~nm}$ \\
\hline [20] & ES & 2004 & 5 materials blocking radiation $<380 \mathrm{~nm}$ \\
\hline [21] & ES & 2013 & 4 materials blocking radiation $<380 \mathrm{~nm}$ \\
\hline [22] & ES & 2009 & 1 material blocking radiation $<380 \mathrm{~nm}$ \\
\hline [23] & UK & 2011 & 1 material blocking radiation $<380 \mathrm{~nm}$ \\
\hline [24] & UK & 2007 & 2 materials blocking radiation $<380 \mathrm{~nm}$ \\
\hline [25] & UK & 2004 & 8 materials blocking radiation $<400 \mathrm{~nm},<405 \mathrm{~nm}$ \\
\hline [26] & GR & 2004 & 3 materials blocking radiation $<380 \mathrm{~nm}$ \\
\hline [27] & GR & 2006 & 3 materials blocking radiation $<380 \mathrm{~nm}$ \\
\hline [28] & GR & 2012 & 3 materials blocking radiation $<380 \mathrm{~nm}$ \\
\hline [29] & RS & 2012 & 1 material blocking radiation $<380 \mathrm{~nm}$ \\
\hline [30] & $\mathrm{DE}$ & 2013 & 1 material blocking radiation $<380 \mathrm{~nm}$ \\
\hline [31] & US & 2006 & 1 material blocking radiation $<380 \mathrm{~nm}$ \\
\hline [32] & AU & 2017 & 1 material blocking radiation $<380 \mathrm{~nm}$ \\
\hline [33] & US & 1999 & 3 materials blocking radiation $<380 \mathrm{~nm}$ \\
\hline [34] & IN & 2015 & 3 materials blocking radiation $<270 \mathrm{~nm},<315 \mathrm{~nm},<395 \mathrm{~nm}$ \\
\hline [35] & IN & 2014 & 3 materials blocking radiation $<270 \mathrm{~nm},<315 \mathrm{~nm},<395 \mathrm{~nm}$ \\
\hline [36] & IN & 2005 & 2 materials blocking radiation $<320 \mathrm{~nm},<400 \mathrm{~nm}$ \\
\hline [37] & IT & 2016 & 2 materials blocking radiation $<312 \mathrm{~nm},<400 \mathrm{~nm}$ \\
\hline [38] & $\mathrm{CH}$ & 2015 & 2 materials blocking radiation $<315 \mathrm{~nm}$ \\
\hline [39] & JP & 1993 & 3 materials blocking radiation $<290 \mathrm{~nm},<320 \mathrm{~nm},<400 \mathrm{~nm}$ \\
\hline [40] & $\mathrm{BE}$ & 2001 & 2 materials blocking radiation $<315 \mathrm{~nm}$ \\
\hline [41] & $\mathrm{DE}$ & 1994 & 4 materials blocking radiation $<280 \mathrm{~nm},<305 \mathrm{~nm},<320 \mathrm{~nm},<360 \mathrm{~nm}$ \\
\hline [42] & $\mathrm{DE}$ & 2009 & 3 materials blocking radiation $<380 \mathrm{~nm}$ \\
\hline [43] & $\mathrm{DE}$ & 2010 & 3 materials blocking radiation $<315 \mathrm{~nm}$ \\
\hline$[44]$ & JP & 2008 & 1 material blocking radiation $<350-400 \mathrm{~nm}$ \\
\hline
\end{tabular}


Table 1. Cont.

\begin{tabular}{llll}
\hline Reference & Country & Year & UV Blocking Materials Studied \\
\hline$[45]$ & ET & 2016 & 1 material blocking radiation $<350 \mathrm{~nm}$ \\
{$[46]$} & JP & 2012 & 4 materials blocking radiation $<340 \mathrm{~nm},<350 \mathrm{~nm},<360 \mathrm{~nm},<400 \mathrm{~nm}$ \\
{$[47]$} & BD & 2016 & 4 materials blocking radiation $<340 \mathrm{~nm},<350 \mathrm{~nm},<360 \mathrm{~nm},<400 \mathrm{~nm}$ \\
{$[48]$} & BD & 2016 & 4 materials blocking radiation $<340 \mathrm{~nm},<350 \mathrm{~nm},<360 \mathrm{~nm},<400 \mathrm{~nm}$ \\
{$[49]$} & US & 2014 & 2 materials blocking radiation $<315 \mathrm{~nm},<380 \mathrm{~nm}$ \\
{$[50]$} & IN & 1997 & 2 materials blocking radiation $<280 \mathrm{~nm},<310 \mathrm{~nm}$ \\
{$[51]$} & JP & 1997 & 2 materials blocking radiation $<290 \mathrm{~nm},<400 \mathrm{~nm}$ \\
{$[52]$} & EG & 2018 & 3 materials blocking radiation $<380 \mathrm{~nm}$ \\
{$[53]$} & UK & 2012 & 3 materials blocking radiation $<380 \mathrm{~nm}$ \\
{$[54]$} & ET & 2014 & 1 material blocking radiation $<315 \mathrm{~nm}$ \\
{$[55]$} & IT & 2019 & 4 materials blocking radiation $<315 \mathrm{~nm}$ \\
{$[56]$} & DE & 2010 & 2 materials blocking radiation $<380 \mathrm{~nm}$ \\
{$[57]$} & AR & 2006 & 1 material blocking radiation $<310 \mathrm{~nm}$ \\
{$[58]$} & SA & 2014 & 1 material blocking radiation $<380 \mathrm{~nm}$ \\
{$[59]$} & ES & 2010 & 1 material blocking radiation $<380 \mathrm{~nm}$ \\
{$[60]$} & EG & 2016 & 3 materials blocking radiation $<380 \mathrm{~nm}$ \\
{$[61]$} & ES & 2010 & 4 materials blocking radiation $<380 \mathrm{~nm}$ \\
{$[62]$} & GR & 2011 & 3 materials blocking radiation $<380 \mathrm{~nm}$ \\
{$[63]$} & US & 2017 & No details \\
\hline
\end{tabular}

\section{Experimental Design, Methodology and Instrumentation Needed to Test UV-Blocking Covering Material}

\subsection{Necessary Equipment and Instruments on Testing a UV Blocking Material}

To measure the UV radiation levels, specific sensors are needed, for the different wavebands. The light sensors under different UV blocking materials could be like the following:

- Global solar radiation sensors,

- Photosynthetically active radiation sensors,

- UVA and UVB radiation sensors.

Once the UV blocking material effect is to be investigated, it is useful to test sensors' UV light absorbance every three to six months because it is well known that this ability fades with time (authors' personal experience and unpublished data).

\subsection{Methodology}

The measurements that a study should conduct in order to confirm that a cladding can attenuate UV solar radiation include the study of plant agronomic characteristics such as height $[4,18,36,39,50-52]$, internode length and number $[4,34,47]$, total leaf area [32,36,39,43,51,52], and dry matter content [34,50,52]. It is also known that yield characteristics, as total and marketable yield, number of fruits and their marketability can be affected by UV blocking covering materials [18-24]. Moreover, the main difference between fruits that have been produced under UV exclusion conditions is that they have a significantly lower content of secondary compounds, pigments and phenolics when they compared with that contained in fruits produced under open field conditions $[19,24,25,33,43,47,53]$.

\section{Effects of UV Blocking Greenhouse Covering Materials on Plant Functions}

\subsection{Effects on Photosynthesis and Respiration}

In Japan, in 1993, the effect of PVC covering materials with different UV radiation transmissivities on the photosynthetic activity of tomato (Solanum lycopersicum L.) and radish (Raphanus raphanistrum L.) plants was studied [39]. They found that the carbon metabolism was always greater under the UV blocking cover, while dark respiration was found not to be promoted by the UV blocking material. 
An increase in photosynthetic activity was also found in mung beans (Vigna radiata L.) [50]. Moreover, in Germany, the effect of three different UV blocking films on a broccoli (Brassica oleracea L.) crop was investigated, where higher $\mathrm{C} / \mathrm{N}$ ratio values were detected under $\mathrm{UV}$ exclusion conditions [42]. Moreover, an increase in gas exchanges, carbonic anhydrase, Rubisco, nitrate reductase activities and total soluble protein content was found in wheat (Triticum aestivum L.) plants [34].

However, a neutral response on photosynthetic rate was found in green and red lettuce (Lactuca sativa L.) [10], and in strawberry (Fragaria $\times$ ananassa L.) plants (cvs. Camarosa and Ventana) [19].

A decrease in the photosynthetic rate of soybean (Glycine max L.) plants was observed under UV blocking covering materials [49]. Also, decreased carbon metabolism (as photosynthetic rate), nitrogen metabolism and protein levels were observed in eggplant (Solanum melongena L.) [51].

Most of the above reports declared that UV blocking covering materials enhanced photosynthetic rate in plant species like tomato, radish, mung bean, broccoli and wheat, and had no effect in eggplant and soybean plants; while in strawberry, green and red lettuce (Lactuca sativa L.) plants, photosynthesis was suppressed. The different results may have occurred due to the fact that Photosystem II (PS II) of some plant species is more sensitive to UVB radiation [7].

A summary of the effects of UV blocking greenhouse covering materials on photosynthesis and respiration is presented in Table 2.

Table 2. Effect of UV blocking covering materials on the Photosynthetic Activity of different plant species.

\begin{tabular}{cccccc}
\hline Reference & Year & Country & Plant & Photosynthesis & Dark Respiration \\
\hline$[39]$ & 1993 & Japan & tomato & $\uparrow^{1}$ & $\downarrow$ \\
{$[39]$} & 1993 & Japan & radish & $\uparrow^{1}$ & \\
{$[51]$} & 1997 & Japan & eggplant & $\downarrow^{1,2}$ & \\
{$[50]$} & 1997 & India & mung bean & $\uparrow^{1}$ & \\
{$[10]$} & 2008 & UK & lettuce & $X$ & \\
{$[42]$} & 2009 & Germany & broccoli & $\uparrow^{3}$ & \\
{$[19]$} & 2009 & Spain & strawberry & $X^{4}$ & \\
{$[49]$} & 2014 & USA & soybean & $\downarrow^{1}$ & \\
{$[34]$} & 2015 & India & wheat & $\uparrow^{1,5}$ & \\
\hline
\end{tabular}

$\uparrow$ : increase; $\downarrow$ : decrease; $X$ : no effects found; 1 : carbon metabolism as photosynthetic rate; 2 : nitrogen metabolism and protein levels; 3 : $\mathrm{C} / \mathrm{N}$ ratio; 4 : content of carbohydrates; 5 : gas exchanges, carbonic anhydrase, Rubisco, nitrate reductase activities and total soluble protein content.

\subsection{Effects on Transpiration}

In a study carried out in Greece, it was stated that the plant height, total leaf area and leaf number were positively affected by the lack of UV radiation [26]. They added that a plant's transpiration rate was thoroughly increased as part of their response to UV exclusion conditions.

As far as the stomatal conductance is concerned, it was found that cut roses (Rosa $\times$ hybrida) stomatal conductance was unaffected under reduced UV light conditions [54], while in wheat plants was higher under the UV blocking covers [35]. The differences noticed in stomatal conductance may be attributed to variations in UVB impact rates of diverse UV sensitivities of various species, but also signify the complexity of UV effects on stomata [5].

\subsection{Effects on Germination and on Seedlings}

In a study carried out in Germany, a UV open and a UV blocking plexiglass cover were compared in order to investigate their effect on sunflower (Helianthus annuus L.) growth, and it was found that the hypocotyl length was reduced by $50 \%$ under the UV blocking material [41]. Hypocotyl elongation growth is an essential step in the seed germination and a key characteristic for plant emergence, influenced by environmental conditions, phytohormones, and is varying among genotypes [64].

Moreover, the total cotyledons area and fresh weight were reduced by $70 \%$, as well as dry weight being reduced by $8 \%$, while seedlings cumulative stem elongation was reduced by $22 \%$ under the 
UV blocking covering material. Moreover, there was a $27 \%$ decrease in sunflower germination. In Japan, it was found that radish and welsh onion (Allium fistulosum L.) germination failure was higher under UV low conditions. It was also found that there was a negative effect on the germination and hypocotyl length of sunflower and blue star (Isotoma axillaris L.) under the UV blocking film [44].

Thus, according to the above, UV blocking covering materials would have a suppressive effect on the growth and development of the germination process, due to the fact that UVB radiation photons are more energetic than visible light photons and, hence, have a stronger effect on the surface of plant cells, causing the ultimate breakdown of seed coating allowing germination to occur [64].

\subsection{Effects on Pigment Synthesis}

During the ripening process, fruit chlorophyll content decreases while other pigments are synthesized. UV ambient light is a crucial factor for the development of many pigments such as carotenoids (i.e., xanthophyll), flavonoids (i.e., anthocyanin), and phenolics. In ripe fruits, chlorophyll still exists but in a small proportion [65]. It has been reported that a lack of $U V$ radiation has a negative effect on pigment synthesis $[66,67]$.

Chlorophyll in tomato and radish leaves was found decreased [39], and also it was observed that the total content of anthocyanins was reduced in eggplant plants [51]. Moreover, flavonoids (kaempferol 3-glucoside) in scots pine (Pinus sylvestris) seedlings in the subarctic region [17], and in arabidopsis (Arabidopsis thaliana L.) plants were also found reduced under UV exclusion conditions [33]. Furthermore, it was observed that total phenolics and phenolic acids content in tomato fruit were affected by cultivar and UV solar radiation [31]. The total amount of phenolic compounds in tomato fruit, as caffeic acid, as well as the content of total phenolics, were reduced by $16 \%$ for both cultivars tested, under the UV blocking cover. Lastly, a decreased concentration of total polyphenols including luteolin, quercetin galactoside and quercetin glucoside was detected in rocket salad (Eruca vesicaria L.) plants grown under a UV blocking cover [55].

In a study in the UK, the effect of two polyethylene films with various transmissivities in the UV radiation, on the phenol content and flavonoid concentration in a red lettuce crop was tested [24]. Moreover, a study carried in UK stated that total content of flavonoids (anthocyanin) and phenolic compounds were decreased under UV blocking film (red and green lettuce) [10]. The same results were also found for strawberry crops under UV blocking films [19]. In Germany, a comparative study was made regarding the total amount of bioactive compounds in greenhouse grown and open field strawberries. The total content of flavonoids, anthocyanins, and kaempferol derivatives, under the UV blocking cover was decreased by approximately 15-35\% [43]. Moreover, strawberry cultivars grown under UV blocking films showed a reduction in total phenolics (ellagic acid) and flavonoid content (anthocyanin). It was also found that the main flavonoid compounds (quercetin and cyanidin) detected in Red Oak lettuce leaf were increasing with the increase in UVB radiation [56]. In China, it was reported that ambient UVB radiation results in delayed growth and development in rapeseed plants (Brassica napus L.). UV radiation seemed to inhibit photo-morphogenesis and chlorophyll production while there was an increase on carotenoid content. Moreover there was a reduction in the accumulation of UVB absorbing compounds in the leaves under the UV blocking film [38].

In India, a positive plant response in pigment synthesis of guar beans (Cyamopsis tetragonoloba L.), urad beans (Vigna mungo L.) and mung beans was detected under films with different transmissivities in UVA radiation [36]. In Argentina, the accumulation of phenolic compounds in arabidopsis was greater in plants grown under UV blocking conditions [57].

The red color parameters detected in eggplants grown under UV blocking films were positively affected, while lightness $\left(\mathrm{L}^{*}\right)$ was unaffected [27]. In UK, strawberry responses under different UV blocking covering films were investigated, and found that the fruit produced under UV blocking films had higher chroma values (by 10-23\%) than under UV open films [25]. In Greece, it was studied the effect of reduced UV radiation on tomato color [28]. When the color measurements took place on harvested fruits, no significant differences were found, while when the color measurements were held 
in vivo, they observed differences in color parameters at the later stages of maturity (light red and red stages). These ripening stages in red colored tomatoes are characterized by the synthesis of red pigmentation (lycopene and $\beta$-carotene), which is affected by the presence of $U V$ radiation. As the authors found no differences in lycopene content, they assumed possible differences in other pigments ( $\beta$-carotene, etc.) content. On the contrary, other authors showed that in tomatoes grown under pearl shade UV blocking films, the lycopene content was found to be decreased [29].

Furthermore, strawberry fruit color is correlated with UV radiation levels [53]. The values of strawberry fruit color were all reported to be significantly higher under a UV blocking cover, followed by the low UV blocking and the UV open film. Moreover, it was found that when peppers (Capsicum annuиm L.) were grown under UV blocking nets they had higher concentration of phenolic compounds during storage. Moreover, higher amounts of ascorbic acid were detected under UV blocking conditions [58]. Lack of UV radiation also resulted in increase in total chlorophyll content in three tropical plants, under the UV blocking films [36]. Moreover, $\mathrm{L}^{*}, \mathrm{a}^{*}$ and $\mathrm{b}^{*}$ parameters values (in upper leaves) of red amaranth were found to be significantly higher under UV exclusion conditions [48], where $L^{*}$ parameters values vary between light $\left(L^{*}=100\right)$ and dark $\left(L^{*}=0\right)$, a* values may vary from green $\left(a^{*}=-50\right)$ to red $\left(a^{*}=50\right)$ and $b^{*}$ values from blue $\left(b^{*}=-50\right)$ to yellow $\left(b^{*}=50\right)$ [28]. Rose petal blackening and appearance of brown spots on white petal cultivars are correlated with the increase in UV radiation levels [54].

White clover showed a neutral response in chlorophyll content (Trifolium repens L.) [40], while the same was stated for cocoplum (Chrysobalanus icaco L.) leaves [18]. While in Spain, a comparative study on two strawberry cultivars (Camarosa and Ventana) under a cellulose acetate and a PE UV blocking film showed no significant differences on the antioxidant activity, the content of carbohydrates and anthocyanin [19]. Moreover, green lettuce plants, cv. Lollo Biondo, showed no phytochemical responses to different UV radiation levels and total phenolics in raspberries (Rubus idaeus L.), and blueberries (Vaccinium Cyanococcus R.) were not affected by the covering material [56].

Strawberry tree (Arbutus unedo L.) and grape vine (Vitis vinifera L.) leaves showed different responses when cultivated under different UV blocking films. On day 191, the plants that grown inside the greenhouses transferred outdoors, and at that day, the total content of flavonols was lower. Later flavonol index in grape vine plants that grow under the UV blocking film was increased significantly when these plants were moved in UV open conditions [37]. In Australia, two plastic films, a UV open and a UV blocking were tested and found a free fraction of phenols (caffeic acid), and flavonoids (cyanidin) under the UV blocking film. Moreover, in all tested sorghum (Sorghum bicolor L.) genotypes, they found higher concentrations of the bound forms of these compounds under the UV blocking film. Moreover, the antioxidant activity was lower under UV blocking treatment for all genotypes [32].

Based on the above studies, as also presented in Table 3, it can be summarized that: (a) chlorophyll content is positively (in $56 \%$ of the studies) or negatively (in $11 \%$ of the studies) affected or is unaffected (in 33\% of the studies) by UV blocking covering materials, (b) flavonoid concentration and phenolic compounds were positively, negatively or not affected by UV blocking covering materials. The discrepancies that have been noticed among the results in the same pigment categories concern different plant species. However, when differences are noticed in the same species, these can be attributed to the different environmental conditions and, more specifically, to the different ambient UV radiation levels. 
Table 3. Effect of UV blocking covering materials on pigment synthesis.

\begin{tabular}{|c|c|c|c|c|c|c|c|}
\hline \multirow{2}{*}{ Reference } & \multirow{2}{*}{ Year } & \multirow{2}{*}{ Country } & \multirow{2}{*}{ Plant Species } & \multicolumn{4}{|c|}{ Pigments } \\
\hline & & & & Chlorophyll & Flavonoid & Phenolic & Carotenoid \\
\hline$[20,21,36,39]$, & $\begin{array}{l}1993,2004 \\
2013,2006\end{array}$ & $\begin{array}{l}\text { Japan, Spain, } \\
\text { USA }\end{array}$ & tomato & $\downarrow$ & & $\downarrow^{3}$ & $x^{7}$ \\
\hline [29] & 2012 & Serbia & tomato & & & & $\downarrow$ \\
\hline [33] & 1999 & USA & arabidopsis & $\uparrow^{2}$ & $\downarrow^{1}$ & $\downarrow$ & \\
\hline$[25,43,52,53]$ & $\begin{array}{l}2004,2012 \\
2010,2010\end{array}$ & UK, Germany & strawberry & & $\downarrow^{1,4,5}$ & $\downarrow$ & \\
\hline$[10,22,24]$ & $\begin{array}{c}2008 \\
2009,2007\end{array}$ & UK, Spain & lettuce & $\uparrow$ & $\downarrow^{1,5}$ & $\downarrow$ & \\
\hline [42] & 2009 & Germany & broccoli & & $\downarrow$ & $\downarrow$ & \\
\hline [47] & 2016 & Bangladesh & broccoli & & $\uparrow$ & & \\
\hline [60] & 2016 & Egypt & cucumber & & $\uparrow$ & & \\
\hline [52] & 2018 & Egypt & cucumber & & $\downarrow$ & $\downarrow$ & \\
\hline [39] & 1993 & Japan & radish & $\downarrow$ & & & \\
\hline [51] & 1997 & Japan & eggplant & & $\downarrow$ & & \\
\hline [17] & 1999 & Finland & pine & & $\downarrow^{1}$ & & \\
\hline [40] & 2001 & Belgium & white clover & $x$ & & & \\
\hline [18] & 2003 & Israel & cocoplum & $x$ & $x$ & & \\
\hline [36] & 2005 & India & guar bean & $\uparrow^{2}$ & $\uparrow$ & & \\
\hline [36] & 2005 & India & urad bean & $\uparrow^{2}$ & $\uparrow$ & & \\
\hline [36] & 2005 & India & mung bean & $\uparrow^{2}$ & $\uparrow$ & & \\
\hline [58] & 2014 & SA & pepper & & & $\uparrow$ & $\downarrow$ \\
\hline [38] & 2015 & China & rapeseed & & $x$ & $\downarrow$ & \\
\hline [34] & 2015 & India & wheat & $\uparrow^{2}$ & & $x$ & \\
\hline [45] & 2016 & Ethiopia & pea & $x$ & $x$ & & \\
\hline [37] & 2016 & Italy & $\begin{array}{l}\text { strawberry } \\
\text { tree }\end{array}$ & & $\downarrow$ & & \\
\hline [37] & 2016 & Italy & grape vine & & $\downarrow$ & & \\
\hline [47] & 2016 & Bangladesh & turnip & & $\uparrow$ & & \\
\hline [48] & 2016 & Bangladesh & red amaranth & & $\uparrow$ & & \\
\hline [32] & 2017 & Australia & sorghum & & & $\downarrow^{3,6}$ & \\
\hline [55] & 2019 & Italy & rocket & & $\uparrow^{1}$ & & \\
\hline
\end{tabular}

\section{Effects of UV Blocking Greenhouse Covering Materials on Plant Architecture and Organs}

\subsection{Effects on Plant Roots, Leaves and Stems}

In Belgium, it was reported that white clover grown under a UV blocking plexiglass cover that blocked $88 \%$ of the solar UV radiation produced significantly higher root biomass (compared with a UV blocking cover that blocked the $82 \%$ of UV ambient radiation [40]), and that soybean plants grown under open field had significantly higher root weight, compared to those grown under a UV deficient environment [49].

Stem elongation in eggplant at the early stages of development was enhanced under UVB exclusion conditions [51]. In USA, it was observed that chrysanthemum (Chrysanthemum indicum L.) and goldenrod (Solidago sp. L.) plant height was slightly increased under UV blocking covers, due to an increased number of internodes, without any effect on internode length, number of branches and number of buds per branch [4], as was also the case for tomato plants under UV blocking materials [20,28]. In addition, eggplant [27] and pepper crops were taller, and had longer stems when grown under UV blocking films or nets [59]. Furthermore, the shoot length of pot rose cultivars was 
found to be increased by 25-35\% [54]. The only exception where a neutral response of plants to UV blocking material was mentioned for cucumber (Cucumis sativus L.) and tomato plants [46].

Cucumber leaf area and dry matter were affected by UV blocking material, showing an increase when they were grown under UV exclusion conditions $[52,60]$. The same positive reaction was also evident in tomato [25], guar, urad and mung beans [36], eggplant [27], radish and welsh onion [44], broccoli and turnip (Brassica rapa L.) seedlings [47], soybean [49] and roses [54]. Lastly, a neutral reaction of plant leaf growth under UV blocking materials was only found in some wheat varieties [34], rapeseed [38], and pea (Pisum sativum) [45], while a negative response was stated for strawberry plants; but this parameter was not affected by the different UV blocking materials [43]. Moreover, red amaranth (Amaranthus tricolor L.) showed a decrease in the total number of leaves, total leaf area and leaf brix when grown under UV exclusion conditions [48].

The above studies regarding the effect of UV blocking material on plant height, leaf number and leaf area presented a positive or neutral response in most of the plant species tested, because of the fact that plants exposed to UV radiation show typically less elongated leaves, stems, and hypocotyls, increased branching of stems and roots, and thicker leaves [7].

A summary of the effects of UV blocking greenhouse covering materials on plant growth are presented in Table 4.

Table 4. Effect of UV blocking material on Stem and Leaf characteristics.

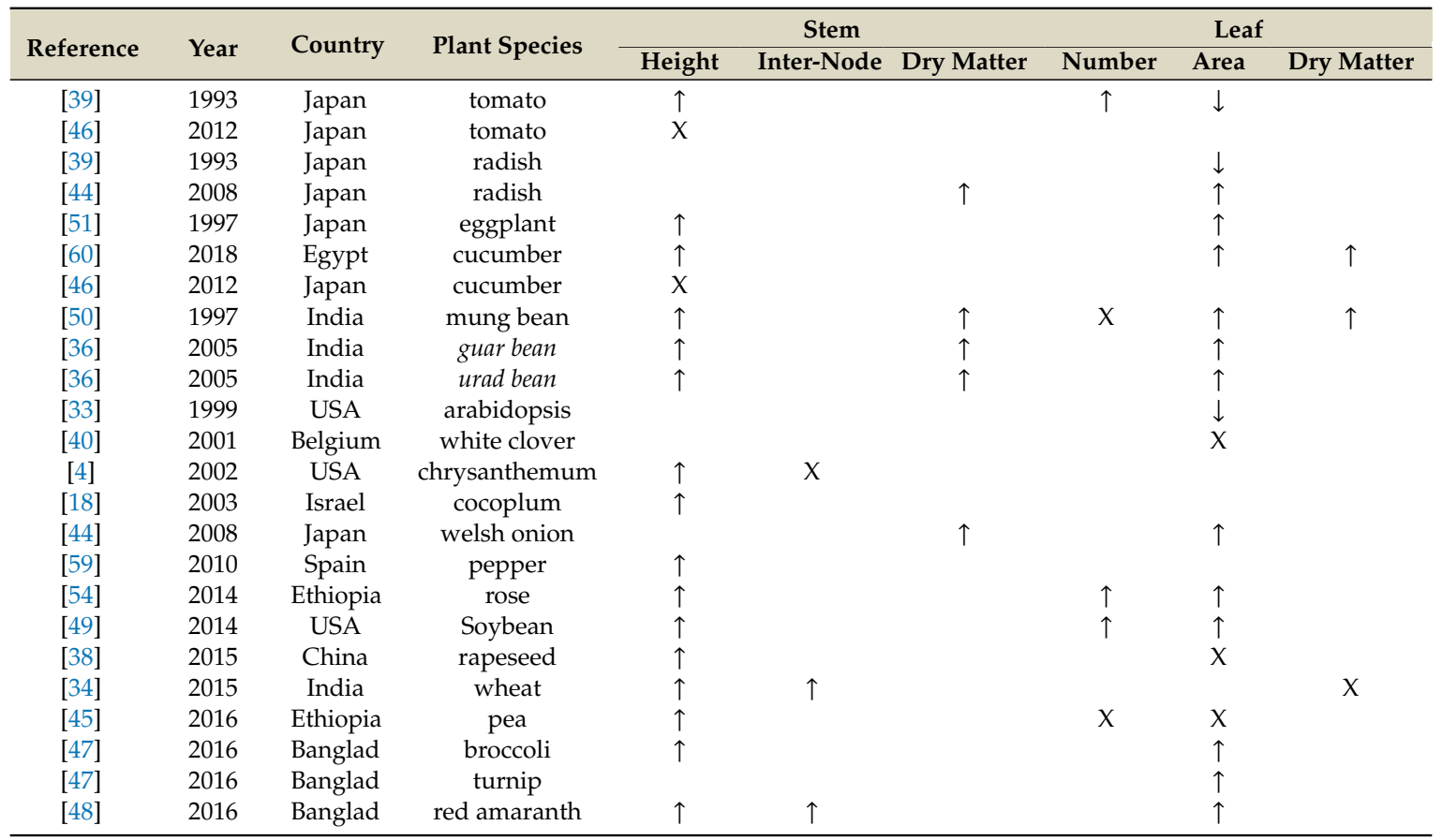

$\uparrow:$ increase; $\downarrow$ : decrease; $X:$ no effects found.

\subsection{Effects on Flowering}

The effect of UV blocking covering materials on flowering has not been studied extensively. In the case of white clover, it was found that there was an increase in number and biomass allocation in flowers [40]. The same results were also found in tomato plants [20].

\subsection{Effects on Fruit Setting}

The positive effect of UV blocking materials on fruit setting has been stated in many studies (Table 5). In Spain, it was found that the number of set fruits in tomato plants was greater under the UV blocking covering material [20]. In Greece, a higher number of marketable fruits and mean fruit weight 
were observed under UV blocking covering materials, while total fruit number and shape, total soluble solids, ascorbic acid, lycopene content, $\mathrm{pH}$ and titratable acidity were found to be unaffected, and finally injuries caused by insects were suppressed [28]. In Spain, a lower number of fruits per $\mathrm{m}^{2}$ were found in tomato plants grown under UV exclusion conditions [21].

Crops such as eggplant [27], strawberries [25] and peppers [58] grown under UV blocking covering materials showed higher marketable yield and significantly lower weight and firmness loss in postharvest storage. In the case of strawberry plants, positive effects are present in most cases $[19,25,43,53]$, while neutral reactions were found only in very few studies $[43,53]$.

Evaluating the results of different reports relevant to the effect of a UV blocking material on fruit setting, the $78 \%$ of reports reported positive effect, the $11 \%$ of them negative and the remain $11 \%$ neutral response, respectively. Most of the discrepancies found on the above results are due to the different environmental conditions during the conduct of the experiments.

Table 5. Effect of UV blocking covering material on fruit.

\begin{tabular}{|c|c|c|c|c|c|c|}
\hline \multirow[b]{2}{*}{ Reference } & \multirow[b]{2}{*}{ Year } & \multirow{2}{*}{ Country } & \multirow{2}{*}{$\begin{array}{c}\text { Plant } \\
\text { Species }\end{array}$} & \multicolumn{3}{|c|}{ Fruit } \\
\hline & & & & Number & Fresh Weight & Marketability \\
\hline$[20,21]$ & 2004,2013 & Spain & tomato & $\uparrow^{1}$ & $\uparrow$ & $\uparrow$ \\
\hline$[19,25]$ & 2004 & Spain, UK & strawberry & $\uparrow$ & $\uparrow^{2}$ & $\uparrow$ \\
\hline$[43,56]$ & 2010 & Germany & strawberry & $\uparrow^{3}$ & $x^{4}$ & \\
\hline$[53]$ & 2012 & UK & strawberry & $x$ & $\uparrow$ & $x$ \\
\hline [27] & 2006 & Greece & eggplant & $\uparrow$ & & \\
\hline [58] & 2014 & SA & peppers & $\uparrow$ & & $\uparrow$ \\
\hline
\end{tabular}

$\uparrow$ : increase; $\downarrow$ : decrease; $X$ : no effects found; 1 : fruit set per plant; 2 : total fruit fresh weight per plant; 3 : mean fruit; 4 : fruit dry matter size.

\section{Effects of UV Blocking Greenhouse Covering Materials Plant Performance}

\subsection{Effects on Yield}

The positive effect of UV blocking covering materials on plant yield was first reported in tomato plants in Japan, where the fresh and dry weight of tomato fruit was found to be greater under the UV blocking cover [39]. In Spain, a 14-19\% increase in tomato total yield and a 37\% increase in marketable yield per plant, when tomatoes grown under the UV blocking film [21].

Furthermore, an up to $60 \%$ increase in the total yield of guar, urad amd mung beans was reported [36]. The same trend was also observed in the case of an eggplant crop where fruit weight was higher under UV blocking conditions [27]. A similar trend was also noticed in lettuce crop (cv. Constance) where fresh and dry weight increased under the UV blocking film [24]. Red lettuce (cv. Revolution) produced $40 \%$ more dry weight under complete UV exclusion conditions [22]. The same results were observed for strawberry [19] and broccoli plants [42]. Strawberries grown under UV blocking covers showed a 20-40\% higher yield [19], while the opposite was reported for melon (Cucumis melo L.) and watermelon (Citrullus lanatus L.) plants, a reduction in yield under UV blocking film due to a decrease in insect activity [68].

It was reported that tomato total yield was increased under pearl shade UV blocking nets [29]. On the Qinghai-Tibetan plateau, rapeseed biomass increased about $12-20 \%$ under UV blocking films [38]. In India, it was found that wheat plants had a greater grain yield under the UV blocking films [34]. Relative results were also obtained in Ethiopia where in open field conditions pea produced more branches compared to the other UV blocking treatments and for both tested altitudes shoot elongation was affected similarly by UV radiation [45].

In Bangladesh, broccoli and turnip seedlings fresh weight was increased by $50-70 \%$, while dry weight did not follow a similar trend and in broccoli seedlings, the highest amounts of dry matter were recorded inside the tunnels that were covered with the UV blocking film that blocked wavelengths shorter than $340 \mathrm{~nm}$, while turnip seedlings' dry matter was higher in plants that grew outdoors [47]. 
In the case of red amaranth, fresh and dry weight were greater under UV-blocking films than under UV open films or in open field [48].

In the case of ornamental plants, the shoot length and number of leaves of three pot rose cultivars were increased (25-35\% and 15-19\%, respectively) under the UV blocking films, and the color of the marketable cut flowers was also optimized [54].

No differences were found on Brussels sprouts' average weight and total yield, but the quality of sprouts was significantly lower under the UV blocking cover [30]. A neutral response to UV radiation levels was also reported for strawberry [43] and tomato plants where only the total yield was unaffected while marketable yield was increased [28]. In Egypt, there are two reports concerning cucumber cultivation under UV blocking materials where a neutral response of the crop was found [52,60].

Welsh onion and radish shoot fresh weight under photoselective red and blue films (low UV levels) was found to be greater than in UV open films. Shoot dry weight was higher under red films followed by blue (UV blocking) and clear film, respectively [44].

In the USA, it was reported that soybean total pod dry weight was lower under UV exclusion conditions, while no differences were observed in total seed weight per plant, individual seed weight, number of nodes, or stem weight [49]. In Spain, it was reported a decrease in lettuce average weight grown under UV blocking nets [22].

Moreover, white clover [40], chrysanthemum and goldenrod plants yield was decreased under UV minus conditions [4].

The effect of UV blocking covering materials on plant yield was thoroughly investigated ( 28 relative papers). The $61 \%$ of them reported in a positive, $11 \%$ negative and $28 \%$ neutral reaction, respectively, concerning different plant species. Moreover, it was reported that the $86 \%$ of the studies revised showed an increase in shoots' fresh and dry weight-results that can be explained by the fact that higher exposure to UV radiation leads to the increased branching of stems [5] (Table 6).

Table 6. Effect of UV blocking covering materials on the yield of different crops.

\begin{tabular}{|c|c|c|c|c|c|c|c|}
\hline \multirow{2}{*}{ Reference } & \multirow{2}{*}{ Year } & \multirow{2}{*}{ Country } & \multirow{2}{*}{ Plant Species } & \multicolumn{4}{|c|}{ Yield } \\
\hline & & & & Fresh Weight & Dry Weight & Shoots & Marketable \\
\hline [40] & 2001 & Belgium & white clover & $\downarrow$ & & & \\
\hline [4] & 2002 & USA & chrysanthemum & & & $\downarrow$ & \\
\hline [4] & 2002 & USA & goldenrods & & & $\downarrow$ & \\
\hline$[21,39]$ & 2012,1993 & $\begin{array}{l}\text { Spain, } \\
\text { Japan }\end{array}$ & tomato & $\uparrow$ & $\uparrow$ & & $\uparrow$ \\
\hline [28] & 2012 & Greece & tomato & $x$ & & & $\uparrow$ \\
\hline [36] & 2005 & India & guar bean & $\uparrow$ & & & \\
\hline [36] & 2005 & India & urad bean & $\uparrow$ & & & \\
\hline [36] & 2005 & India & mung bean & $\uparrow$ & & & \\
\hline [22] & 2009 & Spain & lettuce & & $\uparrow$ & & \\
\hline [27] & 2006 & Greece & eggplant & $\uparrow$ & & & $\uparrow$ \\
\hline [44] & 2008 & Japan & welsh onion & & $\uparrow$ & $\uparrow$ & \\
\hline [19] & 2009 & Spain & strawberry & $\uparrow$ & & & \\
\hline [43] & 2010 & Germany & strawberry & $x$ & & & \\
\hline$[42,47]$ & 2009,2016 & $\begin{array}{l}\text { Germany, } \\
\text { Bangladesh }\end{array}$ & broccoli & $\uparrow$ & $\uparrow$ & & \\
\hline [68] & 2010 & Spain & melon & $\downarrow$ & & & \\
\hline [68] & 2010 & Spain & watermelon & $\downarrow$ & & & \\
\hline [30] & 2013 & Germany & brussels sprouts & $x$ & & & \\
\hline [54] & 2014 & Ethiopia & rose & & & $\uparrow$ & \\
\hline
\end{tabular}


Table 6. Cont.

\begin{tabular}{ccccccc}
\hline \multirow{2}{*}{ Reference } & \multirow{2}{*}{ Year } & Country & Plant Species & \multicolumn{3}{c}{ Yield } \\
\cline { 5 - 6 } & & & Fresh Weight & Dry Weight & Shoots & Marketable \\
\hline$[49]$ & 2014 & USA & soybean & & $\downarrow$ & \\
\hline$[38]$ & 2015 & China & rapeseed & & $\uparrow$ & \\
\hline$[34]$ & 2015 & India & wheat & & & \\
\hline$[45]$ & 2016 & Ethiopia & pea & & & \\
\hline$[60]$ & 2016 & Egypt & cucumber & $X$ & $\uparrow$ & \\
\hline$[47]$ & 2016 & Bangladesh & turnip & $\uparrow$ & $\uparrow$ & \\
\hline
\end{tabular}

$\uparrow:$ increase; $\downarrow$ : decrease; $X$ : no effects found.

\subsection{Effects on Plant Earliness/Senescence}

Flowering earliness and rate of fruit and crop development seems to be affected by UV blocking materials. Studies have shown that the use of UV blocking covers can delay tomato and radish leaf senescence [39]. The same was observed for eggplant plants [51].

Relative results in UK and Spain reported quicker establishment and development of strawberry crops [25] as well as a delay in ripening process [19], when the plants were grown under UV blocking covers. In addition fruit color development of the same plant was also delayed [53].

Moreover, UV blocking material had a negative effect on flowering process of pea plant [45]. Regarding the effect of UV blocking material on plant development, varied results have been emerged. As it concerns leaf aging, $33 \%$ of the relative reports showed a positive response while a $67 \%$ showed a negative. Regarding ripening, $50 \%$ of the studies reported positive response while an equal negative response was also published. Color development and flower delay were both depressed (under UV blocking material) in all the examined cases, due to the limited activity of cryptochromes, which are responsible for the plant development process [6], as shown in Table 7.

Table 7. Effect of UV blocking covering material on plant Development/Earliness.

\begin{tabular}{ccccc}
\hline Reference & Year & Country & Plant Species & Development \\
\hline$[39]$ & 1993 & Japan & tomato & $\downarrow^{1}$ \\
{$[39]$} & 1993 & Japan & radish & $\downarrow^{1}$ \\
{$[51]$} & 1997 & Japan & eggplant & $\uparrow^{1}$ \\
{$[25]$} & 2004 & UK & strawberry & $\uparrow^{2,3}$ \\
{$[19]$} & 2009 & Spain & strawberry & $\downarrow^{3,4}$ \\
{$[45]$} & 2016 & Ethiopia & pea & $\downarrow^{5}$ \\
\hline
\end{tabular}

$\uparrow$ : increase, $\downarrow$ : decrease, X: no differences found, 1 Leaf aging, 2 Establishment, 3 Ripening, 4 Color development, 5 Flowering.

\section{Variations of UV Ambient Radiation Levels on Evaluating Data Regarding UV Blocking Material}

UV radiation levels and spatial distribution of solar UV radiation must be taken into consideration during the evaluation of the results, including the effect of the UV blocking covering material on the crop. Specifically, UV radiation levels exhibit a seasonal variation pattern within the year (Table 8).

For all these reasons, the establishment of a general rule about the response of plants in several levels of UV radiation must be related to the place and the month. It must be mentioned that higher UV radiation levels have been reported in countries near equator where the latitude is near zero, such as Ethiopia (Lat. =6) (Table 8). 
Table 8. UV Index variation in the same place within the year in places regarding UV blocking studies reviewed in this work. Different background colors indicate different UV levels.

\begin{tabular}{cccccccccccccc}
\hline Country (City) & Latitude & J & F & M & A & M & J & J & A & S & O & N & D \\
\hline Argentine (Buenos Aires) & $35^{\circ} \mathrm{S}$ & 9 & 9 & 7 & 4 & 3 & 2 & 2 & 4 & 5 & 7 & 9 & 10 \\
Australia (Perth) & $32^{\circ} \mathrm{S}$ & 12 & 11 & 9 & 6 & 4 & 3 & 3 & 4 & 6 & 8 & 10 & 12 \\
Germany (Berlin) & $52^{\circ} \mathrm{N}$ & 1 & 1 & 2 & 4 & 5 & 7 & 7 & 5 & 3 & 1 & 1 & 0 \\
Greece (Volos) & $39^{\circ} \mathrm{N}$ & 3 & 4 & 5 & 8 & 9 & 9 & 10 & 9 & 7 & 4 & 3 & 2 \\
Japan (Tokyo) & $36^{\circ} \mathrm{N}$ & 2 & 4 & 5 & 8 & 9 & 9 & 10 & 9 & 7 & 4 & 2 & 2 \\
Africa (Ethiopia) & $6^{\circ} \mathrm{S}$ & 12 & 12 & 12 & 12 & 12 & 12 & 12 & 12 & 12 & 12 & 12 & 11 \\
Brazil (Rio de Janeiro) & $23^{\circ} \mathrm{S}$ & 12 & 11 & 9 & 7 & 5 & 5 & 5 & 7 & 9 & 10 & 12 & 12 \\
Cuba (Havana) & $23^{\circ} \mathrm{N}$ & 6 & 8 & 9 & 10 & 10 & 11 & 12 & 11 & 10 & 8 & 6 & 5 \\
Vietnam (Hanoi), ( India) & $21^{\circ} \mathrm{N}$ & 6 & 8 & 10 & 11 & 11 & 11 & 12 & 12 & 10 & 8 & 6 & 6 \\
Spain (Mallorca) & $39^{\circ} \mathrm{N}$ & 2 & 3 & 4 & 6 & 8 & 9 & 9 & 8 & 6 & 4 & 2 & 1 \\
USA (Los Angeles) & $34^{\circ} \mathrm{N}$ & 3 & 4 & 6 & 8 & 9 & 10 & 10 & 9 & 7 & 5 & 3 & 2 \\
\hline
\end{tabular}

Besides that, UV radiation levels vary with the presence of clouds, haze, snow, sun position and altitude. The highest UV radiation levels on Earth can be found in: Peru, Bolivia, Chile and Argentina, where the UV index exceeds 24 [69] in high altitudes (alpine).

According to some representative studies, different responses were found for the same species when the experiments, held in different world areas. Specifically, differences have been found on the plant height of cucumber crops grown in Egypt [52] and Japan [46], although both countries exhibit equal UV radiation levels (Table 9). In detail, in Egypt, plant height was enhanced by the exclusion of UV radiation, while no differences where noticed in Japan. This can be attributed to different responses of species and cultivars to UV radiation levels, due to differences in the genetic background.

In some plant species, responses could be proportional to UV radiation levels. For example, in Germany [42], where UV radiation levels are low, flavonoid index in broccoli plants was found to be lower, in contrast with broccoli plants grown in Bangladesh [47], where UV radiation is higher. Similar responses were noticed in the case of strawberry plants' fresh weight, in experiments conducted in Spain [19] and Germany [43], and in ripening process delays of the same plant, comparing the findings in Spain and the UK [23].

Accordingly, the countries examined in this paper are gathered in five categories regarding UV radiation levels (Table 9).

Table 9. Levels of ambient solar UV radiation in countries mentioned in this work.

\begin{tabular}{cccccc}
\hline Continent & $\mathbf{1} \div \mathbf{2}$ & $\mathbf{3} \div \mathbf{5}$ & $\mathbf{6} \div \mathbf{7}$ & $\mathbf{8} \div \mathbf{1 0}$ & 11 EXTREME \\
& LOW & MODERATE & HIGH & VERY HIGH & \\
& & Italy & & \\
Europe & Serbia & & \\
& Germany & Spain & & \\
& Belgium & Italy & & India \\
Asia & & Greece & & Bangladesh & Florida \\
N. America S. & North & Chan & & Argentina & South Africa \\
America & Carolina & California & & Ethiopia \\
Africa & & Egypt & & Perth & \\
Oceania & & & & \\
\hline
\end{tabular}

\section{Concluding Remarks}

Summarizing the results concerning plant responses on UV blocking material worldwide, it was found that the most examined parameter is the effect of these materials on plant pigments (32 papers), followed by yield ( 28 papers) and leaf area (25), while the least examined plant organs are roots and flowers (2 papers). 
Based on these results, a strong positive or negative effect emerged in chlorophyll or phenolic compounds, respectively, under UV blocking materials, while a more dim response was also reported for flavonoid and carotenoid compounds.

The plant functions that are most affected by UV blocking materials are either enhanced in cases of photosynthesis (found in more than $50 \%$ of 9 relevant reports) in plant species such as tomato, radish, mung bean, broccoli and wheat, or in cases of stomatal conductance (wheat), or transpiration. Plant height and leaf area seem to be positively affected by UV blocking cladding materials. The same is evident also for yield and growth characteristics. However, UV blocking materials suppress the total antioxidant content and other health related phytochemicals, and this is considered by many researchers as the basic disadvantage of this material.

Even though there is a decrease in insecticide use, a decreased pest population enters into greenhouses or nethouses [62]. If other chemicals are applied to plants during the growing season, then these residues on fruits that have been produced under UV blocking conditions are characterized by a more consistent retention [63] after harvest. Lastly, the application of UV blocking materials creates a particular light modification in the plant environment which leads to a better canopy light use efficiency [69].

Author Contributions: Conceptualization, N.K. and C.P.; data curation, A.B. and C.P.; writing—original draft preparation, A.B. and C.P.; writing-review and editing, N.K. and C.P.; supervision, N.K.; project administration, N.K.; funding acquisition, N.K. All authors have read and agreed to the published version of the manuscript.

Funding: This research has been co-financed by the European Union and Greek national funds through the Operational Program Competitiveness, Entrepreneurship and Innovation, under the call RESEARCH—CREATE-INNOVATE (project code: T1EDK-01499).

Conflicts of Interest: The authors declare no conflict of interest.

\section{Abbreviations}

$\begin{array}{lll}\text { SYMBOL } & \text { NAME } & \text { WAVEBAND (nm) } \\ \text { UV } & \text { Ultraviolet } & 280-400 \\ \text { UVA } & \text { Ultraviolet radiation type A } & 320-400 \\ \text { UVB } & \text { Ultraviolet radiation type B } & 280-320 \\ \text { PAR } & \text { Photosyntetically Active Radiation } & 400-700 \\ \text { IR } & \text { InfraRed radiation } & 700-100,000 \\ \text { NIR (or IRA) } & \text { Near InfraRed radiation } & 750-1400 \\ \text { FR } & \text { Far Red } & 700-780\end{array}$

\section{References}

1. Halevy, A. Is there an ideal cover for protected cultivation? In Proceedings of the 14th International Congress for Plastics in Agriculture, Tel Aviv, Israel, 3-7 March 1997; pp. 3-7.

2. Antignus, Y.; Lapidot, M.; Hadar, D.; Messika, Y.; Cohen, S. Ultraviolet-Absorbing screens serve as optical barriers to protect crops from virus and insect pests. J. Econ. Entomol. 1998, 91, 1401-1405. [CrossRef]

3. Costa, H.S.; Robb, K.L. Effects of ultraviolet-absorbing greenhouse plastic films on flight behavior of Bemisia argentifolii (Homoptera: Aleyrodidae) and Frankliniella occidentalis (Thysanoptera: Thripidae). J. Econ. Entomol. 1999, 92, 557-562. [CrossRef]

4. Costa, H.S.; Robb, K.L.; Wilen, C.A. Field trials measuring the effects of ultraviolet-absorbing greenhouse plastic films on insect populations. J. Econ. Entomol. 2002, 95, 113-120. [CrossRef] [PubMed]

5. Hideg, É.; Strid, Å. The effects of UV-B on the biochemistry and metabolism in plants. UV-B radiation and plant life. Mol. Ecol. 2017, 90-110. [CrossRef]

6. Chen, M.; Chory, J.; Fankhauser, F. Light signal transduction in higher plants. Annu. Rev. Genet. 2004, 38, 87-117. [CrossRef] [PubMed]

7. Jansen, M.A.K. Ultraviolet-B radiation effects on plants: Induction of morphogenic responses. Physiol. Plant. 2002, 116, 423-429. [CrossRef] 
8. Jenkins, G.I. Photomorphogenic responses to ultraviolet-B light: Review. Plant Cell Environ. 2017, 40, 2544-2557. [CrossRef]

9. Collalti, A.; Tjoelker, M.A.; Hoch, G.; Makela, A.; Guidolotti, G.; Heskel, M.; Petit, G.; Ryan, M.G.; Battibaglia, G.; Matteucci, G.; et al. Plant respiration: Controlled by photosynthesis or biomass? Glob. Chang. Biol. 2020, 26, 1739-1753. [CrossRef]

10. Tsormpatsidis, E.; Henbest, R.G.C.; Davis, F.J.; Battey, N.H.; Hadley, P.; Wagstaffe, A. UV irradiance as a major influence on growth, development and secondary products of commercial importance in Lollo Rosso lettuce 'Revolution' grown under polyethylene films. Environ. Exp. Bot. 2008, 63, 232-239. [CrossRef]

11. Jansen, M.A.K.; van den Noort, R.E. Ultraviolet-B radiation induces complex alterations in stomatal behavior. Physiol. Plant 2000, 110, 189-194. [CrossRef]

12. Salama, H.M.H.; Al Watban, A.A.; Al-Fughom, A.T. Effect of ultraviolet radiation on chlorophyll, carotenoid, protein and proline contents of some annual desert plants. Saudi J. Biol. Sci. 2011, 18, 79-86. [CrossRef]

13. Lamnatou, C.; Chemisana, D. Solar radiation manipulations and their role in greenhouse claddings: Fresnel lenses, NIR- and UV-blocking materials. Renew. Sustain. Energy Rev. 2013, 18, 271-287. [CrossRef]

14. Giacomelli, G. Components of Radiation: Definition of units, measuring radiation transmission, sensors. Greenhouse Glazing \& Solar Radiation Transmission Workshop. October 1998. Available online: http://horteng.envsci.rutgers.edu/workshop/summary.pdf (accessed on 15 July 2020).

15. Escobedo, J.F.; Gomes, E.N.; Oliveira, A.P.; Soares, J. Ratios of UV, PAR and NIR components to global solar radiation measured at Botucatu site in Brazil. Renew. Energy 2011, 36, 169-178. [CrossRef]

16. IARC Monographs on the evaluation of carcinogenic risks to humans. In Proceedings of the Advisory Group to Recommend Priorities for IARC Monographs during 2015-2019, IARC Internal Report, Lyon, France, 7-9 April 2014; Available online: https://monographs.iarc.fr/wp-content/uploads/2018/08/14-002.pdf (accessed on 15 July 2020).

17. Turunen, M.; Heller, W.; Stich, S.; Sandermann, H.; Sutinen, M.-L.; Norokorpi, Y. The effects of UV exclusion on the soluble phenolics of young Scots pine seedlings in the subarctic. Environ. Pollut. 1999, 106, 219-228. [CrossRef]

18. Nissim-Levi, A.; Kagan, S.; Ovadia, R.; Oren-Shami, M. Effects of temperature, UV-light and magnesium on anthocyanin pigmentation in cocoplum leaves. J. Hortic. Sci. Biotechnol. 2003, 78, 61-64. [CrossRef]

19. Casal, C.; Vilchez, C.; Forjan, E.; De la Morena, B.A. The absence of UV-radiation delays the strawberry ripening but increases the final productivity, not altering the main fruit nutritional properties. Acta Hort. 2009, 842, 159-162. [CrossRef]

20. Monci, F.; Garcia-Andres, S.; Sanchez, F.; Moriones, E.; Espi, E.; Salmeron, A. Tomato yellow leaf curl disease control with UV-blocking plastic covers in commercial plastichouses of Southern Spain. Acta Hort. 2004, 633, 537-542. [CrossRef]

21. Lopez-Marin, J.; Gonzalez, A.; Egea-Gilabert, C.; Fernandez, J.A. Effect of different greenhouse covering photoselective films on yield and quality of tomato. In Proceedings of the VII Congresso Iberico de Agroingenieria y Ciencias Horticolas, Madrid, Spain, 26-29 August 2013.

22. Sal, J.; Velazquez, E.; Legarrea, S.; Aguado, P.; Fereres, A.; Morales, I.; Del Estal, P.; Vinuela, E. Influence of UV-absorbing nets in the population of Macrosiphum euporbiae Thomas (Homopter: Aphididae) and the parasitoid Aphidius ervi (Haliday) (Hymenoptera: Aphidiidae) in lettuce crops. In Proceedings of the 3rd International Symposium on Biological Control of Arthropods, Christchurch, New Zealand, 8-13 February 2009; pp. 329-337.

23. Tsormpatsidis, E.; Henbest, R.G.C.; Battey, N.H.; Hadley, P. The influence of ultraviolet radiation on growth, photosynthesis and phenolic levels of green and red lettuce: Potential for exploiting effects of ultraviolet radiation in a production system. Ann. Appl. Biol. 2011, 156, 357-366. [CrossRef]

24. Garcia-Macias, P.; Ordidge, M.; Vysini, E.; Waroonphan, S.; Battey, N.H.; Gordon, M.H.; Hadley, P.; Jones, P.; Lovegrive, J.; Wagstaffe, A. Changes in the flavonoid and phenolic acid contents and antioxidant activity of red leaf lettuce (Lollo Rosso) due to cultivation under plastic films varying in ultraviolet transparency. J. Agric. Food Chem. 2007, 55, 10168-10172. [CrossRef]

25. Fletcher, J.M.; Tatsiopoulou, A.; Hadley, P.; Davis, F.J. Growth, yield and development of strawberry cv. 'Elsanta' under novel photoselective film clad greenhouses. Acta Hort. 2004, 633, 99-106. 
26. Kittas, C.; Papaioannou, C.; Obeid, D.; Katsoulas, N.; Tchamitchian, M. Effect of two new UV-absorbing greenhouse-covering films on growth and yield of a tomato soilless crop. In Proceedings of the International Symposium of thee CIGR in New trends in Farm buildings, Evora, Portugal, 2-6 May 2004.

27. Kittas, C.; Papaioannou, C.; Obeid, D.; Katsoulas, N.; Tchamitchian, M. Effect of two UV-absorbing greenhouse-covering films on growth and yield of an eggplant soilless crop. Sci. Hortic. 2006, 110, 30-37. [CrossRef]

28. Papaioannou, C.; Katsoulas, N.; Maletsika, P.; Siomos, A.; Kittas, C. Effects of a UV-absorbing greenhouse covering film on tomato yield and quality. Span. J. Agric. Res 2012, 10, 959-966. [CrossRef]

29. Ilic, Z.S.; Milenkovic, L.; Stanojevic, L.; Cvetkovic, D.; Fallik, E. Effects of the modification of light intensity by color shade nets on yield and quality of tomato fruits. Sci. Hortic. 2012, 139, 90-95. [CrossRef]

30. Gulidov, S.; Poehling, H.-M. Control of aphids and whiteflies on Brussels sprouts by means of UV-absorbing plastic films. J. Plant Dis. Prot. 2013, 120, 122-130. [CrossRef]

31. Luthria, D.L.; Mukhopadhyay, S.; Krizek, D.T. Content of total phenolics and phenolic acids in tomato (Lycopersicon esculentum Mill.) fruits as influenced by cultivar and solar UV radiation. J. Food Compos. Anal. 2006, 19, 771-777. [CrossRef]

32. Wu, G.; Bornman, J.F.; Bennett, S.J.; Clarke, M.W.; Fang, Z.; Johnson, S.K. Individual polyphenolic profiles and antioxidant activity in sorghum grains are influenced by very low and high solar UV radiation and genotype. J. Cereal Sci. 2017, 77, 17-23. [CrossRef]

33. Fiscus, E.L.; Philbeck, R.; Britt, A.B.; Booker, F.L. Growth of Arabidopsis flavonoid mutants under solar radiation and UV filters. Environ. Exp. Bot. 1999, 41, 231-245. [CrossRef]

34. Kataria, S.; Guruprasad, K.N. Exclusion of solar UV radiation improves photosynthetic performance and yield of wheat varieties. Plant Physiol. Biochem. 2015, 97, 400-411. [CrossRef]

35. Kataria, S.; Guruprasad, K.N. Exclusion of solar UV components improves growth and performance of Amaranthus tricolor varieties. Sci. Hortic. 2014, 174, 36-45. [CrossRef]

36. Amudha, P.; Jayakumar, M.; Kulandaivelu, G. Impacts of ambient solar UV (280-400 nm) radiation on three tropical legumes. J. Plant Biol. 2005, 48, 284-291. [CrossRef]

37. Grifoni, D.; Agati, G.; Bussotti, F.; Michelozzi, M.; Pollastrini, M.; Zipoli, G. Different responses of Arbutus unedo and Vitis vinifera leaves to UV filtration and subsequent exposure to solar radiation. Environ. Exp. Bot. 2016, 128, 1-10. [CrossRef]

38. Zhu, P.J.; Yang, L. Ambient UV-B radiation inhibits the growth and physiology of Brassica napus L. on the Qinghai-Tibetan plateau. Field Crops Res. 2015, 171, 79-85. [CrossRef]

39. Tezuka, T.; Hottat, T.; Watanabe, I. Growth promotion of tomato and radish plants by solar UV radiation reaching the Earth's surface. J. Photochem. Photobiol. B Biol. 1993, 19, 61-66. [CrossRef]

40. Deckmyn, G.; Cayenberghs, E.; Ceulemans, R. Reduced UV-B in greenhouses decreases white clover response to enhanced $\mathrm{CO}_{2}$. Environ. Exp. Bot. 2001, 46, 117-190. [CrossRef]

41. Ros, J.; Tevini, M. Interaction of UV-radiation and IAA during growth of seedlings and hypocotyl segments of sunflower. Plant Physiol. 1994, 146, 295-302. [CrossRef]

42. Kuhlmann, F.; Muller, C. Independent responses to ultraviolet radiation and herbivore attack in broccoli. Environ. Exp. Bot. 2009, 60, 3467-3475. [CrossRef]

43. Josuttis, M.; Dietrich, H.; Treutter, D.; Will, F.; Linnemannstons, L.; Kruger, E. Solar UVB response of bioactives in strawberry (Fragaria x ananassa Duch. L.): A comparison of protected and open-field cultivation. J. Agric. Food Chem. 2010, 58, 12692-12702. [CrossRef]

44. Hidaka, K.; Yoshida, K.; Shimasaki, K.; Murakami, K.; Yasutake, D.; Kitano, M. Spectrum conversion film for regulation of plant growth. J. Fac. Agric. 2008, 53, 549-552.

45. Roro, A.G.; Terfa, M.T.; Solhaug, K.A.; Tsegaye, A.; Olsen, J.E.; Torre, S. The impact of UV radiation at high altitudes close to the equator on morphology and productivity of pea (Pisum sativum) in different seasons. S. Afr. J. Bot. 2016, 106, 119-128. [CrossRef]

46. Nishizawa, T.; Shishido, Y.; Sasaki, B.; Sato, C.; Hanawa, Y.; Matsumura, K. Effects of specific UV-blocking on plant growth and insect control. Acta Hort. 2012, 927, 203-210. [CrossRef]

47. Solaiman, A.H.M.; Nishizawa, T.; Arefin, S.M.A.; Rahman, M.M.; Sarkar, M.D.; Shahjahan, M. The influence of partial UV-blocking films in the insect infestation and in the growth of broccoli and turnip seedlings. Br. J. Appl. Sci. Technol. 2015, 13, 1-11. [CrossRef] 
48. Solaiman, A.H.M.; Nishizawa, T.; Arefin, S.M.A.; Rahman, M.M.; Sarkar, M.D.; Shahjahan, M. Effect of partially UV-blocking Films on the growth, yield, pigmentation, and insect control of red amaranth (Amaranthus tricolor). Br. J. Appl. Sci. Technol. 2016, 12, 1-11. [CrossRef]

49. Zhang, L.; Allen, L.H., Jr.; Vaughan, M.M.; Hauser, B.A.; Boote, K.J. Solar ultraviolet radiation exclusion increases soybean internode lengths and plant height. Agric. For. Meteorol. 2014, 184, 170-178. [CrossRef]

50. Pal, M.; Sharma, A.; Abrol, Y.P.; Sengupta, U.K. Exclusion of UV-B radiation from normal solar spectrum on the growth of mung bean and maize. Agric. Ecosyst. Environ. 1997, 61, 29-34. [CrossRef]

51. Shiozaki, N.; Tezuka, T. Physiological activation in eggplants by near UV radiation. Plant Cell Physiol. 1997, 38, 1997-2003.

52. Abd El-Aal, H.A.; Rizk, A.M.; Mousa, I.E. Evaluation of new greenhouse covers with modified light regime to control cotton aphid and cucumber (Cucumis sativus L.) productivity. J. Crop Prot. 2018, 107, 64-70. [CrossRef]

53. Ordidge, M.; Garcia-Macias, P.; Battey, N.H.; Gordon, M.H.; John, P.; Lovegrove, J.A.; Vysini, E.; Wagstaffe, A.; Hadley, P. Development of color and firmness in strawberry crops is UV light sensitive, but color is not a good predictor of several quality parameters. J. Sci. Food. Agric. 2012, 92, 1597-1604. [CrossRef]

54. Terfa, M.T.; Roro, A.G.; Olsen, J.E.; Torre, S. Effects of UV radiation on growth and postharvest characteristics of three pot rose cultivars grown at different altitudes. Sci. Hortic. 2014, 178, 184-191. [CrossRef]

55. Mormile, P.; Rippa, M.; Graziani, G.; Ritieni, A. Use of greenhouse-covering films with tailored UV-B transmission dose for growing 'medicines' through plants: Rocket salad case. J. Sci. Food. Agric. 2019, 99, 6931-6936. [CrossRef]

56. Behn, H.; Tittmann, S.; Walter, A.; Schurr, U.; Noga, G.; Ulbrich, A. UV-B Transmittance of greenhouse covering materials affects growth and flavonoid content of lettuce seedlings. Europ. J. Hort. Sci. 2010, 75, 259-268.

57. Caputo, C.; Rutitzky, M.; Ballare, C.L. Solar ultraviolet-B radiation alters the attractiveness of Arabidopsis plants to diamondback moths (Plutella xylostella L.): Impacts on oviposition and involvement of the jasmonic acid pathway. Oecologia 2006, 149, 81-90. [CrossRef] [PubMed]

58. Selahle, K.M.; Sivakumar, D.; Jifon, J.; Soundy, P. Postharvest responses of red and yellow sweet peppers grown under photo-selective nets. Food Chem. 2014, 173, 951-956. [CrossRef] [PubMed]

59. Legarrea, S.; Karnieli, A.; Fereres, A.; Weintraub, P.G. Comparison of UV-absorbing nets in pepper crops: Spectral properties, effects on plants and pest control. Photochem. Photobiol. 2010, 86, 324-330. [CrossRef]

60. Elfadly, E.; El-Aal HAbd Rizk, A.; Sobeih, W. Ambient UV manipulation in greenhouses: Plant responses and insect pest management in cucumber. Acta Hort. 2016, 1134, 343-350. [CrossRef]

61. Lopez-Marin, J.; Gonzalez, T. Effect of ultraviolet-blocking plastic films on insect vectors of virus diseases infesting tomato (Lycopersicon esculentum) in greenhouse. Acta Hort. 2010, 914, 175-180. [CrossRef]

62. Vatsanidou, A.; Bartzanas, T.; Papaioannou, C.; Kittas, C. Efficiency of physical means of IPM on insect population control in greenhouse crops. Acta Hort. 2011, 893, 1247-1254. [CrossRef]

63. Leach, H.; Wise, J.C.; Isaacs, R. Reduced ultraviolet light transmission increases insecticide longevity in protected culture raspberry production. Chemosphere 2017, 189, 454-465. [CrossRef]

64. Noble, R.E. Effects of UV-irradiation on seed germination. Sci. Total Environ. 2002, 299, 173-176. [CrossRef]

65. Ferrer, C.; Costa, J.C. Contenido en clorofilas durante el desarrollo y maduracio'n de frutos de Capsicum annuum L. Acta Hortic. 1991, 8, 269-274.

66. Allen, D.J.; Nogues, S.; Bake, N.R. Ozone depletion and increased UV-B radiation: Is there a real threat to photosynthesis? J. Exp. Bot. 1998, 49, 1775-1788.

67. Caldwell, M.M.; Ballare, C.L.; Bornman, J.F.; Flint, S.D.; Bjorn, L.O.; Teramura, A.H.; Kulandaivelu, G.; Tevini, M. Terrestrial ecosystems, increased solar ultraviolet radiation and interactions with other climatic change factors. Photochem. Photobiol. Sci. 2003, 2, 29-38. [CrossRef] [PubMed]

68. Ben, L.J.; Mckenzie, R.L. Where on Earth Has the Highest UV? National Institute of Water and Atmospheric Research (NIWA): Otago, New Zealand, 2006.

69. Maraveas, C. Environmental sustainability of greenhouse covering materials. A Review. Sustainability 2019, 11, 6129. [CrossRef]

(C) 2020 by the authors. Licensee MDPI, Basel, Switzerland. This article is an open access article distributed under the terms and conditions of the Creative Commons Attribution (CC BY) license (http://creativecommons.org/licenses/by/4.0/). 